\title{
Characterization of membrane-bound lipase from a thermophilic Rhizopus oryzae isolated from palm oil mill effluent
}

\begin{abstract}
The characteristics of the membrane-bound lipase from a thermophilic Rhizopus oryzae were studied. The $\mathrm{pH}$ and temperature optima for lipase activity were at 7.0 and $37^{\circ} \mathrm{C}$, respectively. The enzyme was stable and acidic conditions, retaining more than $80 \%$ of its initial activity at $\mathrm{pH} 4.0$ after $30 \mathrm{~min}$ incubation. It was stable up to $50^{\circ} \mathrm{C}$ with $70 \%$ of initial activity retained after $3 \mathrm{~h}$ incubation. The enzyme is 1,3 specific and exhibits substrate preference. Monoacid triglyceride substrates were hydrolyzed better than methyl esters, polyoxysorbitan and sorbitan substrates.
\end{abstract}

Keyword: Characterization; Lipase; Membrane-bound lipase; Rhizopus oryzae 